\title{
KEPEMIMPINAN KEPALA BADAN KEPEGAWAIAN DAERAH KABUPATEN KATINGAN PROVINSI KALIMANTAN TENGAH
}

\author{
Leadership Of The Head Of Regional Employee Agency, Katingan Provinsi District \\ Central Kalimantan
}

\section{Leda Almuqsith*}

\section{Ardiansyah}

Universitas Muhammadiyah Palangkaraya, Palangka Raya, Central Kalimantan, Indonesia

email: leda.almuqsith@umpalangkaraya.ac..id

\begin{abstract}
Abstrak
Dalam kepemimpinan suatu organisasi, peranan pimpin yang menentukan usaha pencapaiam tujuan organisasi yang dipimpinnya. Hal ini mengandung pengertian bahwa maju mundurnya perjalanan kehidupan organisasi tergantung sampai sejauh mana kemampuan pemimpin tersebut dalam melaksanakan tugas kepemimpinannya. Penelitian ini menggunakan metode kualitatif, yaitu bermaksud mengembangkan konsep, menghimpun fakta dengan ditunjang oleh data yang ada dan digunakan untuk menunjukan dan menjawab apakah masalah tersebut benar. Sumber data terdiri dari data primer (I) sementara yang menjadi sumber data primer adalah pegawai Badan Kepegawaian Daerah Kabupaten Katingan Provinsi Kalimantan Tengah. Teknik pengumpulan data yakni Observasi, wawancara, dan dokumentasi.

Berdasarkan dari hasil penelitian, ditemukan bahwa (I) Kepemimpinan Kepada Badan Kepagawaian Daerah (BKD) Kabupaten Katingan mampu untuk mempengaruhi dalam menentukan tujuan organisasi, memotivasi perilaku bawahan untuk mencapai tujuan, mempengaruhi untuk memperbaiki kelompoknya sehingga tujuan yang diinginkan melalui visi misi dapat tercapai. (2) Kepala Badan Kepegawaian Daerah BKD Kabupaten katingan memperoleh dukungan dan kerjasama dari orang-orang diluar organisasi untuk mencapai tujuan organisasi yang telah direncanakan sebelumnya. (3) Keberhasilan sebuah organisasi Badan Kepegawaian Daerah (BKD) kabupaten katingan tergantung dari kepemimpinan kepala badan kepagawaian daerah kabupaten katingan itu sendiri apakah mampu untuk mempengaruhi, memotivasi perilaku bawahan dan untuk memperbaiki kelompoknya.
\end{abstract}

\begin{abstract}
In the leadership of an organization, the lead role that determines the effort to achieve the goals of the organization he leads. This implies that the progress of the journey of the life of the organization depends on the extent of the ability of the leader in carrying out his leadership duties. This study uses qualitative methods, which are intended to develop concepts, gather facts by being supported by existing data and used to show and answer whether the problem is true. The data source consists of primary data (I) while the primary data source is the employee of the Regional Personnel Agency of Katingan Regency, Central Kalimantan Province. Data collection techniques are observation, interviews, and documentation.

Based on the results of the study, it was found that (I) Leadership of the Regional Civil Service Agency (BKD) of Katingan Regency was able to influence organizational goals, motivate subordinate behavior to achieve goals, influence to improve the group so that the desired goals through vision and mission can be achieved. (2) Head of BKD Regional Personnel Agency, Katingan Regency obtains support and cooperation from people outside the organization to achieve organizational goals that have been previously planned. (3) The success of the Regional Personnel Agency (BKD) of the Katingan district depends on the leadership of the head of the Katingan regency agency itself whether it is able to influence, motivate subordinate behavior and to improve the group
\end{abstract}

\section{PENDAHULUAN}

Dalam kepemimpinan suatu organisasi, peranan pemimpinan yang menentukan usaha pencapaian tujuan organisasi yang dipimpinannya, $\mathrm{Hal}$ ini mengandung pengertian bahwa maju mundurnya perjalanan kehidupan organisasi tergantung sampai sejauh mana kemampuan pemimpin tersebut dalam melaksanakan tugas kepemimpinannya. Telah umum diketahui bahwa setiap organisasi, baik dibidang kenegaraan, keniagaan, politik, social dan organisasi 
kemasyarakatan lainnya, diciptakan atau dibentuk sebagai wahana untuk mencapai suatu tujuan tertentu, baik yang sifatnya jangka panjang, jangka sedang maupun jangka pendek yang tidak mungkin tercapai apabila diusakan oleh para anggotanya yang bertindak sendiri-sendiri.

Kepimpinan Kepala Badan Kepegawaian Daerah Kabupaten Katingan sangat menentukan dalam keberhasilan organisasi tersbut, keberhasilan organisasi terletak dari kepimpinan yang berkualitas dalam memimpin organisasi. Betapapun bagusnya perumusan dan tujuan organisasi, hanya akan sia-sia jika kepemimpinan tidak memperhatikan setiap apa yang dipimpinya, terutama terhadap para bawhanya dalam setiap melaksanakan tugas dan pekerjaan yang telah diberikan.

Pegawai neegri sipil merupakan aparat masyarakat yang bekerja untuk melayani kepentingan masyarakat. Semua kegiatan yang dilakukan ditujukan untuk perbaikan non fisik suatu daerah sesuai dengan ketentuan perundang-perundang yang berlaku.

Bahwa pegawai negeri sipil badan kepegawaian daerah kabupaten katingan kinerjanya masih rendah. Masih ditemukan pegawai neegri sipil yang bolos atau tidak hadir tampa ijin terutama setelah hari libur resmi., pegawai negeri sipil didapati pada tempat-tempat perbelanjaan atau tempat keramaian umum pada saat jam kerja. Selain itu ada beberapa pegawai negeri sipil yang terkesan malas-malasan saat mengerjakan tugas di dalam kantor. Hal-hal tersebut yang menjadikan penilaian masyarakat terhadap sebagaian besar pegawai negeri sipil badan kepegawaian daerah kabupaten katingan.

Rivai (20II:2), Menyatakan bahwa defenisi tentang kepemimpinan bervariasi sebanyak orang yang mencoba mendefinisikan konsep kepemimpinan. Defenisi kepemimpinan secara luas meliputi proses mempengaruhi dalam menentukan tujuan organisasi, memotivasi perilaku pengikut untuk mencapai tujuan, memengaruhi untuk memperbaiki kelompok perolehan dukungan dan kerjasama dari orang-orang di luar kelompok atau organisasi.

Dengan adanya peran kepemimpinan akan mampu menjaga keutuhan kerjasama tiap individu dalam organisasi, mampu menciptakan rasa percaya diri, dan mampu memberikan dorongan kuat pada anggota organisasi melalui tindakan yang menyebabkan orang lain bertindak, merespon, dan menimbulkan perubahan untuk organisasi. Menurut Sagala, (2013:5I) Kepemimpinan (leadership) adalah serangkaian kemampuan dan sifat-sifat keperibadian dalam diri pemimpin itu sendiri seperti kewibawaan, keterampilan, pengetahuan, dan kompetensi untuk dijadikan sebagai sarana meyakinkan orang-orang yang dipimpinnya agar mau dan dapat melaksanakan tugastugas yang dibebankan kepadanya dengan rela, penuh semangat, ada kegembiraan batin, serta merasa tidak terpaksa.

Selaras dengan pengertian kepemimpinan diatas Mullins juga mengungkapkan (Wijono,20I8:I-2), kepemimpinan didasarkan pada sebuah fungsi dari kepribadian yang dapat dilihat dari perilaku yang dinampakan ketika sesorang pemimpin memimpin kelompok maupun organisasi. Dengan kata lain, perilaku kepemimpinan tersebut ditunjukan melalui peran yang dimainkan oleh para pemimpin untuk mencapai kinerja yang efektif dalam memimpin orang lain sebagai pengikutnya di dalam situasi tertentu, baik kelompok maupun di dalam suatu organisasi.

\section{METODOLOGI}

Metode penelitian ini adalah menggunakan metode penelitian kualitatif, penelitian kualitatif digunakan untuk mendapatkan data yang mendalam, suatu data yang mengandung makna, makna adalah data sebenarnya, data yang pasti merupakan suatu nilai dibalik data yang tampak (Sugiyono, 2007 : 3). Alasan 
menggunaksan metode ini untuk mengetahui kepemimpinan kepala badan kepegawaian daerah kabupaten katingan provinsi Kalimantan tengah. Dengan menggunakan metode ini, peneliti berusaha lebih mendekatkan diri kepada objek secara utuh, sehingga mampu menganalisis masalah yang sedang terjadi. Dengan demikian, hasil penelitian ini secara umum akan terwujud deskripsi berupa kata-kata dan kalimat baik dalam analisis maupun kesimpulan sesuai dengan kondisi dilapangan.

\section{HASIL DAN PEMBAHASAN}

Berdasarkan hasil analisis yang dilakukan dalam penelitian ini menunjukan bahwa kepemimpinan kepala Badan Kepegawaian Daerah juga memiliki kemampuan mempengaruhi dalam menentukan tujuan organisasi, memotivasi perilaku pengikut untuk mencapai tujuan, mempengaruhi untuk memperbaiki kelompok dan budayanya, memelihara hubungan kerjasama dan orang-orang diluar kelompok demi pencapaian satu atau beberapa tujuan organisasi yang telah direncanakan sebelumnya.

Menjalin hubungan kerjasama antara atasan dengan bawahannya, hubungan kerjasama antara atasan dan bawahan merupakan sebuah keberhasilan organisasi tersebut untuk mencapai tujuan organisasi. Pemimpin mempermudah dalam mencapai tujuannua dengan membentuk suatu hubungan kerjsama dengan bawahan dan kelompoknya dalam organisasi dan diluar organisasi.

Kepemimpinan Kepala Badan Kepegawaian Daerah sangat diperlukan dalam organisasi tersebur untuk mencapai segala tujuan yang telah direncanakan dan tanpa adanya kepemimpinan Kepala Badan Kepegawaian Daerah tujuan yang telah direncanakan tidak akan tercapai dan tidak akan sesuai dengan tujuan yang direncanakan sebelumnya. Jadi peran kepemimpinan kepala badan kepegawaian daerah sangat penting untuk mencapai tujuan organisasi yang telah direncanakan sebelumnya.

\section{KESIMPULAN}

Berdasarkan dari hasil penelitian dan
pembahasan sebelumnya, maka penulis dapat
mengambil kesimpulan sebagai berikut:

I. Kepemimpinan Kepala Badan Kepegawaian Daerah (BKD) Kabupaten Katingan mampu untuk mempengaruhi dalam menentukan tujuan organisasi, memotivasi perilaku bawahan untuk mencapai tujuan, mempengaruhi untuk memperbaiki kelompoknya sehingga tujuan yang diinginkan melalui visi misinya dapat tercapai.

2. Kepala Badan Kepagwaian Daerah (BKD) Kabupaten Katingan memperoleh dukungan dan kerjasama dari orang-orang diluar organisasi untuk mencapai tujuan organisasi yang telah direncanakan sebelumnya.

3. Keberhasilan sebuah organisais Badan Kepegawaian Daerah (BKD) Kabupaten Katingan tergantung dari Kepemimpinan Kapala Badan Kepegawaian Daerah Kabupaten Katingan itu sendiri apakah mampu untuk menpengaruhi, memotivasi perilaku bawahan dan untuk memperbaiki kelompoknya.

\section{REFERENSI}

Harbani, Pasolong. 2010. Teori Administrasi Publik. Bandung : CV.Alfabeta.

Pasolong, 2014. Teori Administrasi Publik. Cetakan Keenam. Alfabeta: Bandung .

Rivai, Veithzal. 20II. Kepemimpinan dan Perilaku Organisasi. Jakarta : Rajawali Pers.

Sagala, Syaiful. 2013. Pendekatan Dan Model Kepemimpinan. Prenada Media Group.

Siagian, Sodang. 20I0. Teori dan Praktek Kepemimpinan. Jakarta : PT Rineka Cipta.

Soetopo, Hendyatno. 2012. Perilaku Organisasi dan Praktik dibidang Pendidikan. Bandung : PT. Raja Rosda Karya.

Sudarmanto, 2009. Kinerja \& Pengembangan Kompetensi SDM. Yogyakarta : Pustaka Pelajar. 
Sugiyono. 2010. Memahami Penelitian Kualitatif. Bandung: CV Alfabeta.

Wijono, Sutartu. 2014. Kepemimpinan Dalam Perspektif Organisasi. Kencana. 